\title{
Economic Expectations and Satisfaction with Democracy: Evidence from Italy
}

\author{
Matthew Loveless ${ }^{1 \star}$ and Chiara Binelli ${ }^{2}$ \\ ${ }^{1}$ Matthew Loveless, European University Institute and Center for Research and Social Progress, Italy \\ and ${ }^{2}$ Chiara Binelli, Department of Economics, Management and Statistics, University of Milan-Bicocca, \\ and Center for Research and Social Progress, Italy \\ ${ }^{*}$ Corresponding author. Email: m2loveless@gmail.com
}

(Received 14 November 2017; revised 9 May 2018; accepted 29 July 2018; first published online 22 October 2018)

\begin{abstract}
In this article, we argue that individuals' expectations about their future economic prospects are a crucial missing determinant of their degree of satisfaction with democracy. To investigate this link, we collected an original, nationally representative data set on young skilled unemployed Italians using the innovative quantitative expectations data methodology (Manski 2004). Controlling for current local labour market conditions with administrative province-level data and for a rich array of individual-level determinants, we show that those expecting greater job insecurity and instability have lower current satisfaction levels with democracy. By better conceptualizing and operationalizing individuals' expectations, we advance the theoretical framework on satisfaction with democracy and show that expectations are an important and often overlooked determinant of the current level of satisfaction with democratic institutions.
\end{abstract}

Keywords: satisfaction with democracy; subjective expectations; political behaviour; European politics; youth; unemployment

The literature on satisfaction with democracy has either overlooked, under-studied, or poorly operationalized individuals' expectations about the future. While current models control primarily for past experiences and economic evaluations, they fail to meaningfully account for how individuals perceive their future prospects. In this article, we seek to advance the theoretical framework for satisfaction with democracy and show that subjective expectations are an important and often overlooked determinant.

We designed and fielded an innovative survey instrument to collect detailed information on individuals' expectations. We measured these subjective expectations using the quantitative expectations data (QED) methodology, which elicits quantitative and interpersonally comparable information on individuals' subjective probabilities of future expected outcomes (Manski 2004). We administered the survey in 2015 to a nationally representative sample of jobless Italian university 
graduates and matched the survey data with original provincial-level administrative data on the conditions of local labour markets to capture local economic contexts. ${ }^{1}$ The findings confirm the standard model of satisfaction with democracy in the literature. We additionally find that individuals' subjective expectations about their economic futures powerfully affect the degree of current satisfaction with national democratic performance.

Thus, this analysis offers two specific contributions. One, the results suggest that the assessment of subjective expectations benefits from the improved measurement of the QED methodology, which in turn improves the conceptual match of expectations as they are theorized in this literature. Two, subsequently, the results support the notion that subjective expectations are more important determinants of current satisfaction levels than previously acknowledged (Anderson and Guillory 1997; Anderson and O'Connor 2000; Weatherford 1987) and may be potentially valuable to other models of system support (e.g. for EU support, see Simona Guerra's (2013) study of East European youth).

\section{Theory on satisfaction with democracy}

Satisfaction with democracy is a cornerstone of system support (Anderson 2005) and has been argued to originate from individuals' preference for, feelings about, experiences with and performance assessments of democratic institutions (Anderson and Tverdova 2001). At the broadest level, it has been argued that it varies according to the degree of individuals' normative or ideological attachments to democracy as a preferred system of governance (Anderson 2005; Rohrschneider 1999); individual democratic experiences - such as voting, participation or other forms of interaction (Rohrschneider 1999, 2005; Weatherford 1987); and the perception of the government's economic performance (Anderson 1998; Anderson and O'Connor 2000; Dahlberg et al. 2015; Kiewiet 1983; Kinder and Kiewiet 1981).

In addition to examining possible institutional variations (Aarts and Thomassen 2008), more recent work has focused on the nature of electoral outcomes shaping satisfaction such that those identifying with electorally successful parties have higher satisfaction levels (at the individual level) and those identifying with losing parties have lower levels (Anderson and Guillory 1997; see also Blais and Gélineau 2007; Singh et al. 2012). Yet the perceived capacity of democratic institutions to manage the national economy and the resultant effects on personal economic conditions have been at the heart of the literature on individuals' satisfaction with democracy (see also Finkel et al. 1989; Lewis-Beck 1988). As a clearly related example to the investigation here, being unemployed is related to lower aggregate satisfaction with democratic performance (Dahlberg et al. 2015). Thus, the literature appears to have accepted the notion that citizens' satisfaction encompasses the political management of the economy.

\section{Individuals' expectations and satisfaction with democracy}

We argue that what people expect to happen in the future shapes how they might feel about democracy in the present (see Anderson 2005). Economic evaluations are linked to lower satisfaction when the institutions are seen as not having offered, not offering, nor - as we posit here - being able to offer future solutions. That is, in 
addition to a citizen saying, 'I am supportive of my democracy because things have gone well for me' (retrospective egocentric economic evaluation), we can also expect the same citizen to say, 'I am supportive of my democracy because things look as though they will improve for me' (prospective egocentric economic evaluation). This leads to a simple empirical hypothesis: individuals' satisfaction with democracy is positively related to expectations of greater egocentric economic prospects. However, subjective expectations currently represent only a narrow slice of our understanding of satisfaction with democracy because they are underexamined in three key ways: exclusion, inference and poor operationalization.

Of these three, exclusion is the most common (Anderson 2005). In related literatures, current research demonstrates that individuals' support for social provision - such as unemployment benefit, redistribution and job creation efforts by the government - rises among those who expect to become unemployed in the near future (Barfort 2017). Kathryn Simpson and Matthew Loveless (2017) find that while EU citizens are currently dissatisfied with the EU's handling of income inequality, they expect that the EU will perform better in the future. Interestingly, those showing the greatest future optimism are not only those defined by their socioeconomic profiles as economically poor but also those who worry that they might soon become poor. Yet, current models of satisfaction fail to incorporate such expectations about the future in a meaningful way.

The second approach to individuals' expectations is to use inference and proxy expectations as functions of socio-demographic profiles or other individual attributes. An example is the use of the winners/losers hypothesis (Gabel and Palmer 1995) for understanding pre-EU membership support in Central and Eastern Europe (CEE). In CEE, citizens' support for the accession to EU membership was modelled as the outcome of a simple cost-benefit calculation based on their socioeconomic profiles, such that those inferred to benefit from integration were deemed 'winners' of future integration - and thus supporters - and those inferred to fare poorly were 'losers' - and thus less supportive. ${ }^{2}$ Despite theoretical expectations, this approach failed to accumulate consistent support (Gherghina 2010; Guerra 2013; Rohrschneider and Whitefield 2006; Tverdova and Anderson 2004).

The third reason why individuals' expectations are under-examined is poor operationalization. When they are included, subjective expectations are often measured in a rudimentary and outmoded operational form: the 'verbal (or qualitative) expectations data' (VED) methodology. For example, a commonly used VED question on individuals' expectations about national economic performance is: 'And over the next 12 months, how do you think the general economic situation of this country will be? Will it ... get a lot better (1); a little better (2); stay the same (3); get a little worse (4); or get a lot worse (5). ${ }^{3}$ Thus, respondents are asked whether they 'think' or 'expect' that an event will occur and attach a strength of belief, such as 'definitely', 'high chance', 'low chance' or 'not at all', to the likelihood.

While seemingly simple and straightforward, VED questions have been shown to be inadequate in eliciting subjective expectations about the future. As Charles Manski $(2004,2017)$ discusses in two comprehensive surveys of the literature, VED questions present two main limitations. First, interpersonal comparability across 
VED responses is limited by the difficulty of knowing how respondents interpret the questions posed (for example, what is the 'general economic situation of this country'?). Second, there is substantial bias induced by the coarseness of the response options (for example, what is 'a little better'?), which limits the accurate reporting of future uncertainty respondents may perceive but cannot provide. Thus, we argue that the relatively poor performance of expectations when included in empirical models of individuals' behaviour is more likely to be a function of VED methodology rather than a lack of importance of the expectations themselves.

Drawing these together, the three limitations in modelling and measuring expectations - exclusion, inference and poor operationalization - form a negative cycle that undermines the development of meaningful theories in the literature on satisfaction with democracy. Without a reliable test of individuals' expectations, incorrectly specified models run a high probability of omitted variable bias and measurement error. This in turn produces inadequate empirical testing and thus underdeveloped theories. In this article, we confront these limitations by incorporating meaningful measures of individuals' future economic expectations. Specifically, we use the QED methodology to measure individuals' expectations of their future economic prospects, and test the performance of these expectations in a fully specified model of satisfaction with democracy.

\section{Model}

We specify a model in which satisfaction with democracy depends on both actual circumstances and retrospective evaluations, and also, crucially, on individuals' expectations about their future economic prospects, which we measure with the degree of job stability and job security, and the level of future earnings that respondents expect in the near future. We estimate the following individual-level model:

$$
\begin{aligned}
y_{i}= & \beta_{0}+\beta_{1} \text { Expected job stability }_{i}+\beta_{2} \text { Expected job security }_{i}+\beta_{3} \text { Expected earnings }_{i} \\
& +\beta_{4} \text { Sociodemographic }_{i}+\beta_{5} \text { PoliticalEconomic }_{i}+\varepsilon_{i}
\end{aligned}
$$

where $y_{i}$ is individual $i$ 's satisfaction with democracy that is a function of expected job stability, job security and future expected earnings, as well as a rich set of sociodemographic controls and political and economic variables, which we discuss below; $\varepsilon_{i}$ is a normally distributed error term. Equation (1) allows for a direct test of the central hypothesis of this article.

Hypothesis: Individuals' satisfaction with democracy will be higher for those with expectations of greater job stability, job security and higher earnings $\left(b_{1}, b_{2}\right.$ and $b_{3}$ statistically significant and positive).

\section{Data and measurement}

We estimate equation (1) using data collected with an original survey instrument the Italian Youth Employment Survey (IYES) - that we designed to study the future employment and earnings expectations of jobless skilled young people in Italy. We administered the IYES online between January and February 2015 to a 
nationally representative sample of 1,462 Italian university graduates aged 25-34 who were out of employment at the time of the survey and had graduated between 2011 and 2013 from one of the 64 universities that belong to the AlmaLaurea consortium (representing $80 \%$ of all Italian university graduates). Respondents were eligible to complete the survey if they confirmed they were not currently working and aged between 25 and 34. 1,238 young people provided valid answers to both compulsory questions, which made them eligible to take part in the survey, and 1,074 continued to fill in the survey.

The IYES includes 71 questions divided in three main sections: sociodemographic information and political, economic and social attitudes; job search and job experience; occupational and earnings expectations, with a rich battery of quantitative expectations questions on subjective employment probabilities and future expected earnings in different scenarios elicited using the quantitative expectations data methodology. The main innovation of the IYES is the inclusion of this rich battery of quantitative expectations questions, which makes it possible to identify and accurately measure the extent of future job stability, security and earnings' risk that the jobless young expect to face (Binelli 2017).

\section{Satisfaction with democracy}

The dependent variable, satisfaction with democracy, is measured by the widely used question, 'How satisfied are you with the way democracy works in Italy?' The response categories were: very satisfied, satisfied, somewhat satisfied, neither satisfied nor satisfied, somewhat dissatisfied, dissatisfied, very dissatisfied. The response categories range from 1 (very satisfied) to 7 (very dissatisfied), with a mean of 6.18 (St. dev.: 1.09). We note that not a single respondent responded with 'very satisfied' and more than $50 \%$ responded with 'very dissatisfied'. ${ }^{4}$ This variable was reverse coded so that higher scores correspond to higher satisfaction.

\section{Political and economic variables}

At the individual level, the core elements of satisfaction with democracy include three main categories of variable: experiences with democratic institutions (Rohrschneider 1999, 2005); electoral 'winners' and 'losers' (Anderson and Guillory 1997; see also Blais and Gélineau 2007; Curini et al. 2012; Mayne and Hakhverdian 2017; Singh 2014; Singh et al. 2012), including congruence between voters and current government policy positions (Ezrow and Xezonakis 2011; Kim 2009); and the outputs of democratic institutions, primarily their capacity for managing the national economy and the resulting effects on personal economic conditions (Lewis-Beck 1988; also Finkel et al. 1989). ${ }^{5}$

For democratic experience, we use an additive variable that accounts for recent past voting, signing a petition, and participating in a demonstration (see Rohrschneider 2005). For winners and losers, we include a dummy variable for having voted for the 'winning party', Italia Bene Comune, in the 2013 election (1); or not (0). Additionally, to account for 'policy congruence', we use individuals' ideological proximity to the current government. The Comparative Political Data Set (1960-2013) describes the governing party in 2013 as a 'balance of power between left and right'. ${ }^{6}$ Respondents who self-report their political views as 
'centrist' are coded as 'ideological winner' (coded as 1 ; others coded as 0 ), representing generic policy alignment with the governing coalition ('quasi-winners').

Unfortunately, the IYES survey does not include the standard question for retrospective sociotropic economic evaluations. As a proxy measure for this missing variable, we use a question on individuals' perceptions of the actual unemployment rate for their age cohort (25-34, in the last trimester of 2014). We argue that this is a good proxy for two main reasons. First, our respondents are jobless young people, thus an assessment of the unemployment rate for their age group provides a relevant proxy measure of recent economic circumstances that matter to them. We assume that those who under-estimate the actual rate of unemployment evaluate the recent economic performance more positively than those who over-estimate the actual unemployment rate. Second, we can abstract from direct measures of recent past economic performance since the vast majority of our respondents lack meaningful economic experience - through either personal work history or 'independent living'. Therefore, a self-reported measure of an aggregate economic indicator that measures current unemployment provides a reasonable proxy for the missing variable.

Finally, and importantly, including or excluding the individuals' perceptions of the actual unemployment rate does not change the substantive results in the model. This provides some confidence in the results and in the use of this proxy, since the inclusion of the proxy does not affect bivariate correlations between other independent variables and the dependent variable.

One methodological implication of the respondents being jobless is that they do not have an income. We proxy their socioeconomic status by using two main indicators: combined mother's and father's educational levels (Cronbach's alpha: 0.745), and a yes (1) or no (0) answer to the statement, 'My family can help me economically'. Additional controls include individuals' political ideological location; a squared 'ideology' to capture any differential effects of extreme ideological self-location versus moderate self-location; gender; type of university degree; years of working experience, and an interaction term between age and experience to capture potential non-linear effects of experience by age. ${ }^{7}$

\section{Future economic expectations}

We include three measures of individuals' future economic expectations:

- Expectations of job stability: expected probability of finding a job in the next 12 months multiplied by the expected duration of the job.

- Expectations of job security: expected probability of finding a job providing adequate health insurance cover and pension benefits (that is, a higherquality job) in the next 12 months.

- Expected earnings: log of mean expected earnings if finding a job in the next 12 months.

In order to measure individuals' subjective future economic expectations, we use the innovative expectations data collected by the IYES with the QED methodology. As discussed above, the IYES contains a battery of quantitative expectations 
questions on subjective employment probabilities and expected earnings that allow computing accurate measures of the extent of future economic stability, security and earnings' risk (Binelli 2017).

For continuous variables, such as income, the QED methodology elicits information on the future expected value of this variable at different quantiles of the distribution together with the corresponding expected probabilities of realization. For individuals' expected earnings, respondents are asked to report the minimum and the maximum earnings they expect to make, and the subjective probabilities of different quantiles of the earnings' distribution. ${ }^{8}$ With these data, for each individual in the sample, we can construct the complete distribution of expected future earnings, and therefore all of its moments, such as the mean expected earnings, which we use as one measure of future economic expectations.

For discrete variables, such as the probability of finding a job, the QED methodology elicits individuals' subjective probability of future realizations. We construct two measures of job security and job stability using the subjective probability of finding a job that offers adequate health cover and pension benefits as a measure of job security, and the likelihood of finding a job in the next 12 months multiplied by individuals' expected job duration as a measure of job stability. For both variables, a higher score represents, respectively, expectations of higher job stability and job security. These indicators are both consistent with the previous literature on job stability and security (Manski and Straub 2000) and, as discussed above, provide more accurate measures than those constructed using verbal expectations data (Manski 2014, 2017).

\section{Macro variables}

In addition to individual-level variables, the standard model for satisfaction with democracy also includes a number of macro variables. Several studies have examined satisfaction with democracy cross-nationally, comparing variation across party systems, such as majoritarian vs. multi-party (Aarts and Thomassen 2008; Anderson and Guillory 1997), executive-legislative power balance and number of interest groups (Bernauer and Vatter 2012) and mean voter position (Ezrow and Xezonakis 2011). Satisfaction with democracy has been shown to be particularly sensitive to variations in economic performance, explained primarily by sociotropic economic issues and perceptions of the government's economic performance (see Anderson 1998; Kiewiet 1983; Kinder and Kiewiet 1981).

In order to account for the economic context where individuals form expectations, we compiled an original data set at the Italian Social Security Institute (Istituto Nazionale della Previdenza Sociale - INPS) to measure economic variation across all 110 Italian provinces. ${ }^{9}$ Using the population data by province, we constructed variables for the environment of the population of 25-34-year-olds in each Italian province as the mean value for January and February 2015 to match the data collection period of the IYES.

We computed mean earnings, the percentage of both temporary and very temporary jobs, and the amount of unemployment subsidies to control for local labour market conditions and aggregate measures of employment stability, security and earnings (Lühiste 2013). Although bivariate correlations do not suggest strong 
relationships $(n=941 ; r=0.09, r=-0.06, r=0.02, r=-0.06$, respectively), we expect that those in poor provinces have worse economic outlooks than those in wealthier provinces. We thus allow satisfaction with democracy to vary by province through the impact of local labour market conditions in the respondent's province of residence. To do so, we allow $\beta_{0}$ in equation (1) to be province-specific as a function of the aggregate measures of actual earnings, employment stability and security:

$$
\begin{aligned}
\beta_{0 j}= & \gamma_{00}+\gamma_{01} \text { Mean Earnings } j+\gamma_{02} \% \text { Temp jobs }_{j}+\gamma_{03} \% \text { Very Temp jobs } \\
& +\gamma_{04} \text { Unemploy.Subsidies }_{j}+\mu_{0 j}
\end{aligned}
$$

Combining equations (1) and (2), we estimate a multilevel, mixed random- and fixed-effects model:

$$
\begin{aligned}
& y_{i j}=\gamma_{00}+\gamma_{01} \text { Mean Earnings } s_{j}+\gamma_{02} \% \text { Temp jobs }_{j}+\gamma_{03} \% \text { Very Temp jobs } \\
& +\gamma_{04} \text { Unemployment Subsidies }_{j}+\beta_{1 j} \text { Expected job stability }_{i j} \\
& +\beta_{2 j} \text { Expected job security }_{i j}+\beta_{3 j} \text { Expected earnings }_{i j} \\
& +\beta_{4 j} \text { Sociodemographic }_{i j}+\beta_{5 j} \text { PoliticalEconomic }_{i j}+\mu_{0 j}+\varepsilon_{i j}
\end{aligned}
$$

Table 1 presents summary descriptive statistics of the variables included in the model. The Appendix provides details of the scales of each variable. The overall satisfaction levels (mean 1.82 on a 1-6 scale) and democratic experience (3.32 on a 0-7 scale) are low. Just over a quarter (28\%) are 'electoral winners' while just over half $(56 \%)$ are quasi-winners (ideologically close to the ruling coalition). The sample is predominantly female (62\%), under 30, and with little work experience. Of the sample, $84 \%$ report that they can turn to their family of origin if they have financial difficulties, and $68 \%$ of the sample have both parents that have at most a

Table 1. Descriptive Statistics of the IYES Survey and the INPS Data

\begin{tabular}{lcccl}
\hline Individual-level data & Obs. & Mean & St. dev. & Range \\
\hline Satisfaction with democracy & 942 & 1.82 & 1.09 & $1-6$ \\
Winner & 947 & 0.28 & 0.45 & $0-1$ (dummy) \\
Quasi-winner & 947 & 0.56 & 0.50 & $0-1$ (dummy) \\
Retrospective economic evaluation & 921 & -20.00 & 18.70 & $-81-19$ \\
Democratic experience & 911 & 3.32 & 1.94 & $0-7$ \\
Job stability & 839 & 75.53 & 75.45 & $0-400$ \\
Job security & 946 & 30.02 & 24.60 & $0-100$ \\
Expected earnings & 947 & 1070.86 & 606.55 & $115-7825$ \\
Ideological position & 840 & 3.35 & 1.32 & $1-7$ \\
(Ideological position) & & 2.18 & 2.14 & $0-9$ \\
Male & 840 & 0.38 & 0.49 & $0-1$ (dummy) \\
Age & 946 & 27.70 & 2.28 & $25-34$ \\
Level of education & 938 & 1.70 & 0.73 & $1-4$ (dummies) \\
Work experience & 947 & 2.93 & 1.64 & $1-6$ \\
Parents' education & 945 & 7.72 & 1.72 & $2-12$ \\
Family help & 940 & 0.84 & 0.37 & $0-1$ \\
& 945 & 1254.93 & 185.25 & $1010.8-855.8$ \\
Gross earnings in euros & 946 & 1.81 & 4.16 & $0-40.70$ \\
Percentage of temporary jobs & 946 & 3423.77 & 601.08 & $1010.0-4326.7$ \\
Unemployment subsidies in euros & 946 & 946 & 5.58 & $0-37.45$ \\
Percentage of very temporary jobs & 94.48 & &
\end{tabular}


high-school degree (diploma di scuola superiore), thus the sample is characterized by high upward educational mobility.

The young in the sample face a high degree of both job instability and insecurity: $60 \%$ perceive a low probability of finding a job in the next 12 months, and over $70 \%$ expect to be employed for at most one year, over half of the sample for at most six months. Up to $80 \%$ expect a less than $50 \%$ chance that they will find a job that offers adequate health insurance cover and pension benefits. The mean expected net monthly earnings in the sample is just above $€ 1,000$ per month, which, as Chiara Binelli (2017) discusses, closely matches the mean of actual earnings data for this age/education group in Italy.

The model has been estimated using both logit and OLS regressions with robust standard errors. Since the results are substantively the same, we present OLS regressions for ease of interpretation.

\section{Empirical results}

The main regression results reported in Table 2 are informative. Across Models 2, 3 and 4, the political and economic attributes - when significant - perform as expected. Specifically, voting for the winning party and more positive retrospective economic evaluations produce higher levels of satisfaction. In particular, the strong and consistent effect of 'winning' on support for democracy is consistent with the literature (Anderson and Guillory 1997; Singh et al. 2012), although not for the more generic 'ideological' winners (Ezrow and Xezonakis 2011; Kim 2009). Democratic experience is negatively related to satisfaction in Model 2 although this negative relationship becomes insignificant in the larger models. We note that similar results have been found for Portugal, Spain and Greece, where, although the normative appeal of democracy remains, individuals' levels of political engagement are often negatively correlated with satisfaction with democracy (Weßels 2015). Controlling for socio-demographic profiles (in Models 3 and 4), we find that males are less likely to be satisfied and the higher education of parents - although not their economic support - is positively related to satisfaction levels. Individuals' ideological location, age, working experience or type of degree did not have any significant effect on satisfaction levels.

At the same time, all three economic expectations variables are statistically significant in the full models. In these models (3 and 4), individuals' expectations of greater job stability and security correspond to greater satisfaction with democracy. This also means that those who expect greater insecurity and instability have lower satisfaction (see Figure 1).

The finding that those who expect higher earnings from their eventual employment show lower satisfaction with democracy initially appear counterintuitive. Yet, if we consider either end of this 'negative' relationship, possible explanations exist. For example, satisfaction with democracy may be of greater importance to those who expect to earn less, if simply as a means to combat systemic market inequalities (Bollen and Jackman 1985; Reuveny and Li 2003; Whitefield and Loveless 2013). Alternatively, those expecting higher incomes may be more demanding of political institutions and their performance and, as such, be more dissatisfied with their actual performance. 
Table 2. Future Economic Expectations and Satisfaction with Democracy

\begin{tabular}{|c|c|c|c|c|}
\hline & $\begin{array}{c}\text { (1) } \\
\text { Sat w Dem }\end{array}$ & $\begin{array}{c}(2) \\
\text { Sat w Dem }\end{array}$ & $\begin{array}{c}\text { (3) } \\
\text { Sat w Dem }\end{array}$ & $\begin{array}{c}\text { (4) } \\
\text { Sat w Dem }\end{array}$ \\
\hline \multicolumn{5}{|l|}{ Future economic expectations } \\
\hline Expected job stability & $\begin{array}{l}0.000995 \\
(1.81)\end{array}$ & $\begin{array}{l}0.000933 \\
(1.65)\end{array}$ & $\begin{array}{l}0.00135^{\star} \\
(2.31)\end{array}$ & $\begin{array}{l}0.00133^{\star} \\
(2.30)\end{array}$ \\
\hline Expected job security & $\begin{array}{l}0.0110^{\star \star \star} \\
(7.47)\end{array}$ & $\begin{array}{l}0.00964^{\star \star \star} \\
(6.61)\end{array}$ & $\begin{array}{l}0.00840^{\star \star \star} \\
(5.49)\end{array}$ & $\begin{array}{l}0.00856^{\star \star \star} \\
(5.85)\end{array}$ \\
\hline Expected earnings & $\begin{array}{l}-0.000203^{\star \star} \\
(-3.57)\end{array}$ & $\begin{array}{l}-0.000191^{\star \star} \\
(-3.17)\end{array}$ & $\begin{array}{l}-0.000244^{\star \star \star} \\
(-4.35)\end{array}$ & $\begin{array}{l}-0.000248^{\star \star \star} \\
(-4.33)\end{array}$ \\
\hline \multicolumn{5}{|l|}{ Economic/political variables } \\
\hline Winning party voter & & $\begin{array}{l}0.653^{\star \star \star} \\
(7.73)\end{array}$ & $\begin{array}{l}0.663^{\star \star \star} \\
(7.98)\end{array}$ & $\begin{array}{l}0.675^{\star \star \star} \\
(8.04)\end{array}$ \\
\hline Ideological winners & & $\begin{array}{l}0.0312 \\
(0.45)\end{array}$ & $\begin{array}{l}0.0196 \\
(0.14)\end{array}$ & $\begin{array}{l}0.0603 \\
(0.43)\end{array}$ \\
\hline Retrospective economic evaluation & & $\begin{array}{l}0.00371 \\
(1.68)\end{array}$ & $\begin{array}{l}0.00491^{*} \\
(2.34)\end{array}$ & $\begin{array}{l}0.00491^{*} \\
(2.28)\end{array}$ \\
\hline Democratic experience & & $\begin{array}{l}-0.0481^{\star} \\
(-2.17)\end{array}$ & $\begin{array}{l}-0.0379 \\
(-1.52)\end{array}$ & $\begin{array}{l}-0.0400 \\
(-1.54)\end{array}$ \\
\hline \multicolumn{5}{|l|}{ Socio-demographic controls } \\
\hline Respondent's ideological self-ID & & & $\begin{array}{l}0.0362 \\
(0.94)\end{array}$ & $\begin{array}{l}0.0279 \\
(0.72)\end{array}$ \\
\hline $\begin{array}{l}\text { Respondent's ideological self-ID position } \\
\text { squared }\end{array}$ & & & $\begin{array}{l}-0.00976 \\
(-0.33)\end{array}$ & $\begin{array}{l}-0.000940 \\
(-0.03)\end{array}$ \\
\hline Male & & & $\begin{array}{l}-0.135^{\star} \\
(-2.01)\end{array}$ & $\begin{array}{l}-0.145^{\star} \\
(-2.16)\end{array}$ \\
\hline Age & & & $\begin{array}{l}-0.0271 \\
(-0.94)\end{array}$ & $\begin{array}{l}-0.0272 \\
(-0.95)\end{array}$ \\
\hline Years of working experience & & & $\begin{array}{l}-0.139 \\
(-0.65)\end{array}$ & $\begin{array}{l}-0.152 \\
(-0.72)\end{array}$ \\
\hline Age ${ }^{\star}$ ears of working experience & & & $\begin{array}{l}0.00452 \\
(0.62)\end{array}$ & $\begin{array}{l}0.00507 \\
(0.70)\end{array}$ \\
\hline Parents' combined education & & & $\begin{array}{l}0.0741^{\star \star \star} \\
(3.52)\end{array}$ & $\begin{array}{l}0.0774^{\star \star \star} \\
(3.63)\end{array}$ \\
\hline Economic help from family & & & $\begin{array}{l}0.00148 \\
(0.02)\end{array}$ & $\begin{array}{l}-0.00553 \\
(-0.06)\end{array}$ \\
\hline Respondent's level of education & & & & \\
\hline Advanced undergraduate degree & & & $\begin{array}{l}-0.0305 \\
(-0.39)\end{array}$ & $\begin{array}{l}-0.0390 \\
(-0.50)\end{array}$ \\
\hline Postgraduate degree & & & $\begin{array}{l}-0.0826 \\
(-0.70)\end{array}$ & $\begin{array}{l}-0.0884 \\
(-0.75)\end{array}$ \\
\hline $\mathrm{PhD}$ & & & $\begin{array}{l}0.0795 \\
(0.26)\end{array}$ & $\begin{array}{l}0.0448 \\
(0.15)\end{array}$ \\
\hline Province-level data & & & & \\
\hline Mean earnings & & & & $\begin{array}{l}0.000175 \\
(0.74)\end{array}$ \\
\hline Unemployment subsidies & & & & $\begin{array}{l}0.0000384 \\
(0.48)\end{array}$ \\
\hline$\%$ temporary jobs & & & & $\begin{array}{l}-0.0166^{\star} \\
(-2.12)\end{array}$ \\
\hline$\%$ very temporary jobs & & & & $\begin{array}{l}-0.0183^{\star \star \star} \\
(-3.46)\end{array}$ \\
\hline Constant & $\begin{array}{l}1.602^{\star \star \star} \\
(20.61)\end{array}$ & $\begin{array}{l}1.658^{\star \star \star} \\
(10.87)\end{array}$ & $\begin{array}{l}1.895 \\
(2.11)\end{array}$ & $\begin{array}{c}1.863 \\
(1.88)\end{array}$ \\
\hline Observations & 804 & 757 & 686 & 686 \\
\hline Wald Chi-squared & 70.14 & 194.94 & 270.36 & 336.12 \\
\hline Prob. & 0.0000 & 0.0000 & 0.0000 & 0.0000 \\
\hline
\end{tabular}

Source: Italian Youth Unemployment Project (IYES) 2015 and INPS data. Notes: t-statistics in parentheses; ${ }^{\star} p<0.05 ;{ }^{\star \star} p<0.01 ;{ }^{\star \star \star} \mathrm{p}<0.001$. 

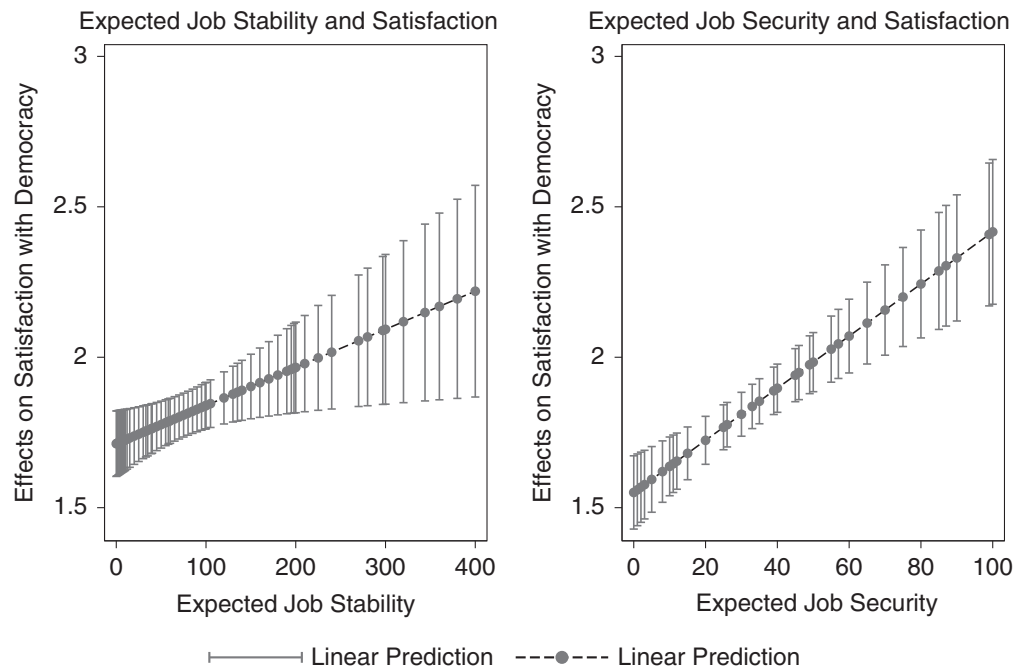

Figure 1. Average Marginal Effect of Expected Job Stability and Job Security Source: IYES (2015).

There are some limitations to comparing relative strengths of independent variables in a multilevel model. However, if we generate standardized betas by estimating the model with OLS regression, we can get a sense of which variables are producing the biggest effects. Here, the most powerful variables are the 'electoral winners' (0.275), followed directly by 'job security' (0.177) and 'expected earnings' (0.138). 'Job stability' (0.076) has a smaller but statistically significant effect. These relatively powerful performances in the standard model of satisfaction with democracy supply evidence that expectations are more salient determinants than previously acknowledged. More importantly, using the improved conceptual and operational match for subjective economic expectations with the QED methodology, this finding prompts us to revisit and update existing theories that have relied on outdated concepts and methods.

In Model 4, we include provincial-level variation in economic contexts. Doing so provides greater robustness to the individual-level model as we control for highly specified economic contexts for each respondent. The percentage of both temporary and very temporary jobs are statistically significant and, as would be expected, negatively related to satisfaction levels. Neither mean earnings nor unemployment subsidies are statistically significant. In any case, individuals' local economic context, as measured by provincial-level data, changes the results of the individual-level model. This corresponds to related work in which there are some, if inconsistent, correlations between variation in satisfaction at the local level (Weitz-Shapiro 2008; for unemployment in the US, see Books and Prysby 1999). ${ }^{10}$

\section{Discussion}

Unemployment is not only about not having a job, but also about the prospect of finding another job. In addition to the absence of payslips, it introduces significant 
uncertainty into individuals' choices about the future: whether to move, get married or have children (Binelli 2017), and, as we have shown in this article, current support for democracy. While the analysis here focuses on a specific subpopulation of Europe (highly skilled jobless youth in Italy), it provides a compelling example of the importance of including quantitative measures of expectations in models of satisfaction with democracy.

The central limitation of this study originates from the nature of these data; namely, the sample of young, college-educated Italians may initially appear to limit the generalizability of this study. While we have made every effort to replicate work in the literature and examined these data across highly varied provincial settings in Italy, the sample is narrow. However, young jobless university graduates represent an overlap of several current crises in Europe. Given that other socio-demographic groups - older, unskilled - potentially face higher instability and more insecurity, these results represent a 'lower bound' or a best-case scenario. Thus, it is possible to see the observed relationships in this analysis feeding into larger questions of national and supra-national support, the rise of outsider/challenger parties and the destabilization of party systems in Europe. For example, in the case of Italy, although beyond the immediate scope of this study, the electoral successes of Movimento 5 Stelle, Casapound and Lega reflect one political consequence of a frustrated European youth (Ceccarini and Bordignon 2016). Thus, this sample is potentially representative of larger Europe-wide phenomena after the economic crisis which has appeared to cultivate substantive challenges to democratic governance and long-term legitimacy (Simpson and Loveless 2017).

Our findings show that expectations are an important channel through which increased unemployment among the young threatens support for democracy, since the frustrations of the unemployed have long been known to have political consequences (Dahlberg et al. 2015; Schlozman and Verba 1979). While democratic satisfaction has declined in Italy, particularly among the young, this mirrors falling satisfaction with national democracy across Europe, particularly among the young (Armingeon and Guthman 2014; Cordero and Simón 2016). ${ }^{11}$ Aggregate, longterm patterns of declining satisfaction with democracy affect the likelihood of sustainable democratic governance. Additionally, a more general warning is that not only are unemployed college graduates an increasingly common phenomenon in Italy and other countries in Europe, but also their chronic unemployment conflicts with the long-standing notion that 'higher education' is a pathway to success. Therefore, as we argue here, while the sample may limit broad generalization, the results suggest that the economic prospects of EU citizens have to be taken more seriously.

The improved handling of the conceptual and operational nature of individuals' expectations may have several potential, positive and direct implications beyond the study of satisfaction with democracy. As an extensive empirical literature has shown, quantitative reliable measures of individuals' expectations are significant determinants of several present choices and behaviours such as educational, marriage and fertility choices, as well as labour market participation and consumption behaviour (see Delavande et al. 2011 and Manski 2004, 2017 for extensive reviews of the literature). As such, we expect the QED methodology to contribute to the development of several models of political behaviour as 
individuals' expectations become salient determinants of political attitudes and behaviours.

It should be borne in mind that we use expectations that refer to the next 12 months. Primarily, we suspect that finding a job soon is more valuable than finding a similar job five years from now. While we could theoretically assert a subjective difference between long and short term, it is common in the QED literature to collect 12-month forecasts to increase accuracy and reliability of the provided answers. Longer-run quantitative subjective expectations become increasingly unreliable since individuals cannot be assumed to provide consistent accurate forecasts and probability distributions over a very long time horizon.

Finally, it is possible that respondents with low satisfaction with democracy also have low economic expectations because the system is 'broken'. We note that one missing element that has been found to affect satisfaction with democracy is corruption (Stockemer and Sundström 2013; Weitz-Shapiro 2008). Unfortunately, the IYES does not include a question on individuals' perceptions of corruption. ${ }^{12}$ Yet, we argue that the 'system' not supplying the jobs is the market, not democracy. Alternatively, if Italian graduates did not trust politicians to solve societal problems, this might affect how they saw their future job prospects. However, we are examining neither the trust of politicians nor their competence. As the literature has demonstrated, we take satisfaction as an indicator of performance evaluation on the procedural function of political institutions (Anderson 2005). That is, while trust in specific politicians and satisfaction with the entire Italian government may move together (however loosely), they are separate and can be examined accordingly.

\section{Conclusion}

The notion that future performance or outcomes could drive individuals' current decisions is a crucial component of early forms of rational theories about political behaviour. Anthony Downs (1957), for example, argued that citizens would cast their votes for candidates based on what the candidates promised to deliver if elected. In this article, we investigate the impact of individuals' expectations about their economic futures on how satisfied they are with the performance of their national democracy. Specifically, we argue - and find evidence - that subjective expectations of future job stability, job security and earnings shape current satisfaction.

This study demonstrates the relevance of individuals' expectations about their future for satisfaction with democracy by employing the quantitative expectations data methodology, which overcomes current methodological limitations that have prevented a proper accounting of future expectations in current models of satisfaction with democracy. By better conceptualizing and operationalizing individuals' expectations, we advance the theoretical framework on satisfaction with democracy and show that expectations about future economic situations are an important and often overlooked determinant of current satisfaction. In addition, by focusing on a sample of jobless Italian young people, the results voice the frustrations of unemployment, and the lack of substantial efforts to alleviate it, which do not bode well for satisfaction with democracy - and thus long-term legitimacy at the national and supranational levels in Europe. 


\section{Appendix: Measurement}

Political ideology: Where would you place yourself politically? (1) extreme left; (2) left; (3) centre left; (4) centre; (5) centre right; (6) right; (7) extreme right.

Squared political ideology: (Political ideology - mean $)^{2}$.

Winner: Dummy variable $=1$ if respondent voted for Italia Bene Comune (leader Pier Luigi Bersani) in 2013 election. Otherwise $=0$.

Ideological winner: According to the Comparative Political Data Set 1960-2013 (Armingeon et al. 2015), the 2013 government showed a 'Balance of power between left and right' (govparty); therefore dummy variable $=1$ if respondent self-reported a centrist political ideology (i.e.: 3,4 or 5). Otherwise $=0$.

Retrospective economic evaluation: Actual unemployment rate for 25-34-year-olds with university degrees in Italy group (19\%) subtracted from respondent's answer about this rate.

Democratic experience: Additive variable if respondent voted in 2013 election (yes $=1 ;$ no $=0$ ), signed a petition, or demonstrated recently (for both: never $=0$; once $=1 ; 2-5$ times $=2$; and 6 or more times $=3$ ); Cronbach's alpha: 0.509 .

Gender: Dummy variable: male $=1$.

Age: Respondent's age.

Work experience: Considering all the work for which respondent received an income and also unpaid if carried out in a family-owned concern, how many years of work experience has he/she accumulated? (1) no work experience; (2) less than 1 year; (3) 1-2 years; (4) 3-4 years; (5) 5-6 years; (6) more than 6 years.

Education: Dummy variable that can take one of four values: (1) undergraduate degree; (2) advanced undergraduate degree; (3) postgraduate degree; (4) PhD. Reference category: undergraduate degree.

Socioeconomic status (1): Additive combination of parents' education: What is the highest level of education achieved by your parents? (1) nessun titolo di studio [No education]; (2) licenza elementare [elementary education]; (3) licenza media [middle school education]; (4) diploma di scuola superiore [high school diploma]; (5) laurea [university degree]; (6) specializzazione post-laurea (compresi master) [master's degree]; (7) dottorato di ricerca [PhD]. Cronbach's alpha: 0.745 .

Socioeconomic status (2): Expectation of family help: If you were in economic difficulties, could you count on financial help from your family? yes $=1$; no $=0$.

Job stability: Expected job duration (less than 6 months, between 6 and 12 months, between 1 and 3 years, 4 or more years) times expected probability to find a job in the next 12 months.

Job security: Probability (0-100\%) of finding a job that offers adequate health coverage and pension benefits in the next 12 months.

Expected earnings: Logarithm of mean expected earnings computed using the questions on the minimum, maximum and the probability of expected earnings at least equal to average expected earnings if individuals were to find a job in the next 12 months. These are the questions in detail:

(1) 'Assume that you will start working in the next 12 months, what is the minimum monthly net amount that you expect to be able to earn? What is the maximum monthly net amount that you expect to be able to earn?' 
(2) 'On a scale from 0 to 100 , what is the probability that your monthly net earnings will be at least equal to the average monthly earnings between the minimum and the maximum monthly net earnings that you expect to be able to earn? In other words, if you were to assign a number between 0 and 100 to the probability that you will earn at least the average of the monthly earnings between the minimum and the maximum monthly earnings that you expect to be able to earn, what would this number be? $0=$ you are certain that your earnings will be lower than the average between the minimum and the maximum earnings that you expect to be able to earn. $100=$ you are certain that your earnings will be at least as high as the average between the minimum and the maximum earnings that you expect to be able to earn.'

Acknowledgements. This paper was supported by the VisitINPS Scholars Program (Italy) for the project: 'Expectations of Job Instability, Job Insecurity and Earnings Risk of the Italian Skilled Unemployed: Patterns and Impact on Behaviour' (Istituto Nazionale della Previdenza Sociale 2016-17). We would like to thank Shane Singh, the editors, and the three anonymous reviewers for their comments which significantly improved our article. Any remaining errors remain our own.

\section{Notes}

1 The administrative data come from the Istituto Nazionale della Previdenza Sociale (INPS), the Italian equivalent of the US Social Security Administration or UK National Insurance Administration.

2 These profiles included various arrays of individuals' levels of income, education, skill sets and positions defined by occupational groups (see Gabel and Palmer 1995).

3 VED questions are common in many large cross-national surveys: World Values Surveys; the European Values Surveys; the European Elections Surveys, the American and British National Election Studies, the Eurobarometer series, and the International Social Survey Programme.

4 Despite the positive skew of the dependent variable, the residuals are normally distributed and the variance of error terms are similar across the values of the independent variables; thus, the model is valid and robust to its current specification.

5 We will test prospective egocentric economic expectations controlling for both retrospective sociotropic economic evaluations and retrospective egocentric economic evaluations. Prospective sociotropic economic expectations are not included because of a lack of data and a norm in the literature of including all four evaluations.

6 www.cpds-data.org; variable 'govparty'.

7 The Appendix describes all measurement variables in detail. We note that other than the interaction and the main effect of 'years of working experience' in the interaction of 'age*years of working experience', there is no evidence of multi-collinearity among any other included variables.

8 Several surveys include a module with quantitative expectations questions: earnings expectations questions are included in the US Survey of Economic Expectations (www.disc.wisc.edu/archive/econexpect) and the Italian Survey of Household Income and Wealth (www.bancaditalia.it/statistiche).

9 These data were collected during the summer of 2016 as part of the VisitINPS Scholars Program (Italy) for the project: 'Expectations of Job Instability, Job Insecurity and Earnings Risk of the Italian Skilled Unemployed: Patterns and Impact on Behavior' [Istituto Nazionale della Previdenza Sociale 2016-17].

10 We also note that in the literature the theoretical impact of macro-economic contexts is identified from national-level variation, which makes it potentially less applicable to our single-country case study here. 11 By comparing the 2004 and 2012 European Social Surveys (EES), in Italy, in 2004, for those aged 35 and younger, satisfaction with democracy $(1=$ very dissatisfied to $10=$ very satisfied $)$ has a mean of 4.81 (St. dev.: 2.0) with $\mathrm{n}=426$; in 2012, the mean is 3.94 (St. dev.: 2.2) with $\mathrm{n}=279$ (t-test of difference in means 5.41 with $\mathrm{p}<0.000)$. www.europeansocialsurvey.org.

12 However, we note that, given Italy's near-annual electoral turnover over the past 50 years, corruption and related scandals may have diminished citizens' satisfaction levels (see Kumlin and Esaiasson 2012). 


\section{References}

Aarts K and Thomassen J (2008) Satisfaction with Democracy: Do Institutions Matter? Electoral Studies 27(1), 5-18.

Anderson CJ (1998) Parties, Party Systems, and Satisfaction with Democratic Performance in the New Europe. Political Studies 4, 572-588.

Anderson CJ (2005) Good Questions, Dubious Inferences, and Bad Solutions: Some Further Thoughts on Satisfaction with Democracy. Center on Democratic Performance Working Paper, No. 116. Binghamton University, Department of Political Science, http://cdp.binghamton.edu.

Anderson CJ and Guillory CA (1997) Political Institutions and Satisfaction with Democracy: A Cross-National Analysis of Consensus and Majoritarian Systems. American Political Science Review 91(1), 66-81.

Anderson CJ and O'Connor KM (2000) System Change, Learning and Public Opinion about the Economy. British Journal of Political Science 29, 215-240.

Anderson CJ and Tverdova Y (2001) Winners, Losers, and Attitudes Toward Government in Contemporary Democracies. International Political Science Review 22(4), 321-338.

Armingeon K and Guthman K (2014) Democracy in Crisis? Declining Support for National Democracy in European Countries. European Journal of Political Research 53(3), 423-442.

Armingeon K, Isler C, Knöpfel L, Weisstanner D and Engler S (2015) Comparative Political Data Set 1960-2013. Bern: Institute of Political Science, University of Berne.

Barfort S (2017) The Effect of Income Expectations on Social Policy Preferences. Working Paper. London School of Economics and Political Science, https:/sebastianbarfort.github.io/papers/barfort2017expectations. pdf.

Bernauer J and Vatter A (2012) Can't Get No Satisfaction with the Westminster Model? Winners, Losers and the Effects of Consensual and Direct Democratic Institutions on Satisfaction with Democracy. European Journal of Political Research 51(4), 435-468.

Binelli C (2017) Employment and Earnings Expectations of Jobless Young Skilled: Evidence from Italy. CeRSP Working Papers Series, WP15/01, https://cersp.org/cersp-working-paper-1502-employment-andearnings-expectations-of-jobless-young-skilled-evidence-from-italy.

Blais A and Gélineau F (2007) Winning, Losing and Satisfaction with Democracy. Political Studies 55(2), 425-441.

Bollen K and Jackman R (1985) Political Democracy and the Size Distribution of Income. American Sociological Review 50(4), 438-457.

Books J and Prysby C (1999) Contextual Effects on Retrospective Economic Evaluations: The Impact of the State and Local Economy. Political Behavior 21(1), 1-16.

Ceccarini L and Bordignon F (2016) The Five Stars Continue to Shine: The Consolidation of Grillo's 'Movement Party' in Italy. Contemporary Italian Politics 8(2), 131-159.

Cordero G and Simón P (2016) Economic Crisis and Support for Democracy in Europe. West European Politics 39(2), 305-325.

Curini L, Jou W and Memoli V (2012) Satisfaction with Democracy and the Winner/Loser Debate: The Role of Policy Preferences and Past Experience. British Journal of Political Science 42(2), 241-261.

Dahlberg S, Linde J and Holmberg S (2015) Democratic Discontent in Old and New Democracies: Assessing the Importance of Democratic Input and Governmental Output. Political Studies 63(1), 18-37.

Delavande A, Gine X and McKenzie D (2011) Measuring Subjective Expectations in Developing Countries: A Critical Review and New Evidence. Journal of Development Economics 109, 203-216.

Downs A (1957) An Economic Theory of Democracy. New York: Harper Collins.

Ezrow L and Xezonakis G (2011) Citizen Satisfaction with Democracy and Parties' Policy Offerings. Comparative Political Studies 44(9), 1152-1178.

Finkel SE, Muller EN and Seligson MA (1989) Economic Crisis, Incumbent Performance and Regime Support: A Comparison of Longitudinal Data from West Germany and Costa Rica. British Journal of Political Science 19(3), 329-351.

Gabel M and Palmer H (1995) Understanding Variation in Public Support for European Integration. European Journal of Political Research 27(1), 3-19. 
Gherghina S (2010) Unraveling Romance: An Assessment of Candidate Countries' Support for the EU. Comparative European Politics 8, 444-467.

Guerra S (2013) Does Familiarity Breed Contempt? Determinants of Public Support for European Integration and Opposition to it Before and After Accession. Journal of Common Market Studies 51, $38-50$.

Kiewiet DR (1983) Macroeconomics and Micropolitics. Chicago: University of Chicago Press.

Kim M (2009) Cross-National Analyses of Satisfaction with Democracy and Ideological Congruence. Journal of Elections, Public Opinion and Parties 19(1), 49-72.

Kinder DR and Kiewiet DR (1981) Sociotropic Politics: The American Case. British Journal of Political Science 11(2), 129-161.

Kumlin S and Esaiasson P (2012) Scandal Fatigue? Scandal Elections and Satisfaction with Democracy in Western Europe, 1977-2007. British Journal of Political Science 42(2), 263-282.

Lewis-Beck MS (1988) Economics and Elections: The Major Western Democracies. Ann Arbor: University of Michigan Press.

Lühiste K (2013) Social Protection and Satisfaction with Democracy: A Multi-Level Analysis. Political Studies 622(4), 784-803.

Manski CF (2004) Measuring Expectations. Econometrica 72(5), 1329-1376.

Manski CF (2017) Survey Measurement of Probabilistic Macroeconomic Expectations: Progress and Promise. National Bureau of Economic Research Working Paper 23418.

Manski CF and Straub JD (2000) Worker Perceptions of Job Insecurity in the Mid-1990s: Evidence from the Survey of Economic Expectations. Journal of Human Resources 35(2), 447-479.

Mayne Q and Hakhverdian A (2017) Ideological Congruence and Citizen Satisfaction: Evidence from 25 Advanced Democracies. Comparative Political Studies 50(6), 822-849.

Reuveny R and Li Q (2003) Economic Openness, Democracy, and Income Inequality: An Empirical Analysis. Comparative Political Studies 36(5): 575-601.

Rohrschneider R (1999) Learning Democracy. Oxford: Oxford University Press.

Rohrschneider R (2005) Institutional Quality and Perceptions of Representation in Advanced Industrial Democracies. Comparative Political Studies 38(5), 850-874.

Rohrschneider R and Whitefield S (2006) Political Parties, Public Opinion and European Integration in Post-Communist Countries: The State of the Art. European Union Politics 7, 141-160.

Schlozman KL and Verba S (1979) Injury to Insult: Unemployment, Class, and Political Response. Cambridge, MA: Harvard University Press.

Simpson K and Loveless M (2017) Another Chance? Concerns about Inequality and Support for both the European Union and Further Integration. Journal of European Public Policy 24(7), 1069-1089.

Singh SP (2014) Not All Election Winners are Equal: Satisfaction with Democracy and the Nature of the Vote. European Journal of Political Research 53(2), 308-327.

Singh S, Karakoc E and Blais A (2012) Differentiating Winners: How Elections Affect Satisfaction with Democracy. Electoral Studies 31(1), 201-211.

Stockemer D and Sundström A (2013) Corruption and Citizens' Satisfaction with Democracy in Europe: What is the Empirical Linkage? Zeitschrift für Vergleichende Politikwissenschaft 7(1), 137-157.

Tverdova YV and Anderson CJ (2004) Choosing the West? Referendum Choices on EU Membership in East-Central Europe. Electoral Studies 23(2), 185-208.

Weatherford MS (1987) How Does Government Performance Influence Political Support? Political Behavior 9(1), 5-28.

Weitz-Shapiro R (2008) The Local Connection: Local Government Performance and Satisfaction with Democracy in Argentina. Comparative Political Studies 41(3), 285-308.

Weßels B (2015) Political Culture, Political Satisfaction and the Rollback of Democracy. Global Policy 6, 93-105.

Whitefield S and Loveless M (2013) Social Inequality and Social Conflict: Evidence from the New Market Democracies of Central and Eastern Europe. Europe-Asia Studies 65(1), 26-44.

Cite this article: Loveless M and Binelli C. 2020. Economic Expectations and Satisfaction with Democracy: Evidence from Italy. Government and Opposition: An International Journal of Comparative Politics 55:

413-429. doi: 10.1017/gov.2018.31 